Hydrology and Earth System Sciences, 8(6), 1065-1075 (2004) C EGU

\title{
Water dynamics in a laurel montane cloud forest in the Garajonay National Park (Canary Islands, Spain)
}

\author{
G. García-Santos ${ }^{1}$, M. V. Marzol ${ }^{1}$ and G. Aschan ${ }^{2}$ \\ ${ }^{1}$ University of La Laguna, Department of Geography, Ctra. Tacoronte-Tejina 233, $1^{\circ}, 38350$ Tenerife, Canary Islands, Spain \\ ${ }^{2}$ University of Duisburg-Essen, Applied Botany - FB9, Essen, Germany \\ E-mail for corresponding author: glendagarciasantos@yahoo.es
}

\begin{abstract}
Field measurements from February 2003 to January 2004 in a humid (but dry in summer) crest heath wood-land (degraded laurel forest) in the National Park of Garajonay, Canary Islands (Spain), were combined to calculate water balance components. The water balance domain is at the surface of the catchment and is controlled by atmospheric processes and vegetation. This study found that annual water income (rainfall plus fog water) was $1440 \mathrm{~mm} \mathrm{year}^{-1}$, half of which was occult (or fog) precipitation, while stand transpiration estimated from measurements of sap flow amounted, annually, to $40 \%$ of potential evapotranspiration calculated from measurements of meteorological variables. The positive role of crest laurel forests, which transpire less water than is incoming from rain and fog is emphasised.
\end{abstract}

Keywords: laurel forest, fog interception, stand transpiration, sap flow, hydrological cycle

\section{Introduction}

Laurel forest, 'laurisilva', a subtropical vegetation of evergreen trees partly covered by epiphytes, is an ancient vegetation type, widespread in southern Europe and the Mediterranean region before the climate changes at the end of the Tertiary and the beginning of the Quaternary period. Today, the remnants of the laurel forest occur predominantly on the northern slopes of the Macaronesian Islands (Azores, Canary Islands, Cape Green and Madeira) between 800 and $1300 \mathrm{~m}$ a.s.l., where stratocumulus clouds transported by the trade winds produce a uniform climate with little temperature variation $\left(8^{\circ} \mathrm{C}\right)$ and high air humidity $(75 \%)$ throughout the year (Marzol, 1993; Dorta,, 1996).

Forest ecosystems are central to the control of erosion processes and catchment hydrology especially in mountainous regions with steep slopes and relatively high rainfall (Cavelier and Goldstein, 1989). Studying hydrological processes in these mountain forests is important in assessing the regional hydrological cycle and estimating groundwater recharge, which is the main water resource of the western Canary Islands, where the upward exploitation of natural water resources (Tenerife: $216 \cdot 10^{6} \mathrm{~m}^{3}$ year $^{-1}$ ) exceeds the downward groundwater recharge $\left(201 \cdot 10^{6} \mathrm{~m}^{3}\right.$ year $\left.^{-1}, 2000\right)$ (Consejo Insular de Aguas de Tenerife, 2000). Recharge is difficult to estimate as the difference term in the water balance because the main components of the hydrological cycle, rainfall, rain and fog intercepted by the vegetation, the amounts lost by evaporation and transpiration and the changes in soil moisture storage are all known only approximately (Kämmer, 1974; Aboal et al., 2000, Marzol, 2002).

Under the climatological conditions prevailing in a cloud belt, evaporation from intercepted water may represent a substantial proportion of the total evapotranspiration from the forest ecosystem from a surface energy balance or atmospheric perspective. However, this evaporative loss may not be of hydrological significance since fog interception may exceed evaporation (Höllermann, 1981; Aschan et al., 1994). In this case, transpiration by the vegetation may account for the principal water loss. Therefore, estimating seasonal and annual transpiration in Canaries laurel forests is essential for calculating stand and regional water balances.

Previous studies on evaporation from laurel forest have been focused mainly on a small remnant forest in the Agua Garcia mountains in Tenerife (Aschan et al., 1997; Jimenez 
et al., 1996, 1999; Aboal, 1998); until now, appropriate hydrological information has been lacking for the large forests in the central part of La Gomera Island. Although these two islands are close, differences in the density of vegetation (mostly Erica arborea L. at the crest in La Gomera Island) may cause differences in the water inputs; the experimental plot at the north crest in La Gomera at $1300 \mathrm{~m}$ a.s.l is undisturbed, strongly exposed to the trade winds and much higher than Aboal's plot (820-830 m a.s.l) in Tenerife; therefore, it is expected that the water balance is different for the two sites.

The present work aims to determine an annual water balance of the forest using micro-meteorological techniques and direct measurements of transpiration from the humid crest heath forest stand at the highest altitude of La Gomera Island.

\section{Materials and Methods}

\section{STUDY AREA AND EXPERIMENTAL PLOT}

The study area is in the Garajonay National Park, on La Gomera (Canary Islands, Spain) (Fig. 1), where one of the largest existing remnants of endangered ancient crest heath woodland vegetation is protected. The climate in this area is humid Mediterranean, with annual precipitation of $750 \mathrm{~mm}$ and a mean annual temperature of $13.6{ }^{\circ} \mathrm{C}$ (Marzol et al., 1990).

A catchment of approximately $44 \cdot 10^{4} \mathrm{~m}^{2}$ in the central sector of the summit, exposed to trade winds under the influence of the 'sea of clouds' was chosen at $28.1284590^{\circ}$ $\mathrm{N}, 17.2593380^{\circ} \mathrm{W}$ (Fig. 1). The upper parts of the area are covered with degraded laurel forest 'humid (dry in summer) crest heath forest' (Pérez de Paz et al., 1990; Golubic, 2001). This forest, 'degraded' by human activities and overgrazing, is more resistant to dry conditions than laurels. With a mean height of approximately $10 \mathrm{~m}$, it comprises mainly heather (Erica arborea L.) partly covered by epiphytic bryophytes, wax-myrtle (Myrica faya Ait.), laurel (Laurus azorica Seub. Franco) and, to a lesser extent, holly (Ilex canariensis Poivet). Within the catchment, the experimental plot of $300 \mathrm{~m}^{2}$ is located on a steep slope (30-40\%), oriented to the North, close to the mountain crest at $1300 \mathrm{~m}$ a.s.1. (Fig.2). In this area, soil depth increases gradually from the top of the crest (small rocky area) to the heath forest $(0.5-1 \mathrm{~m})$. Tree roots are assumed to penetrate the whole soil profile. Tree density is 0.13 stems per $\mathrm{m}^{2}$, with a mean height of $9 \mathrm{~m}$, a mean projected crown area of $6 \mathrm{~m}^{2}$ and a mean leaf
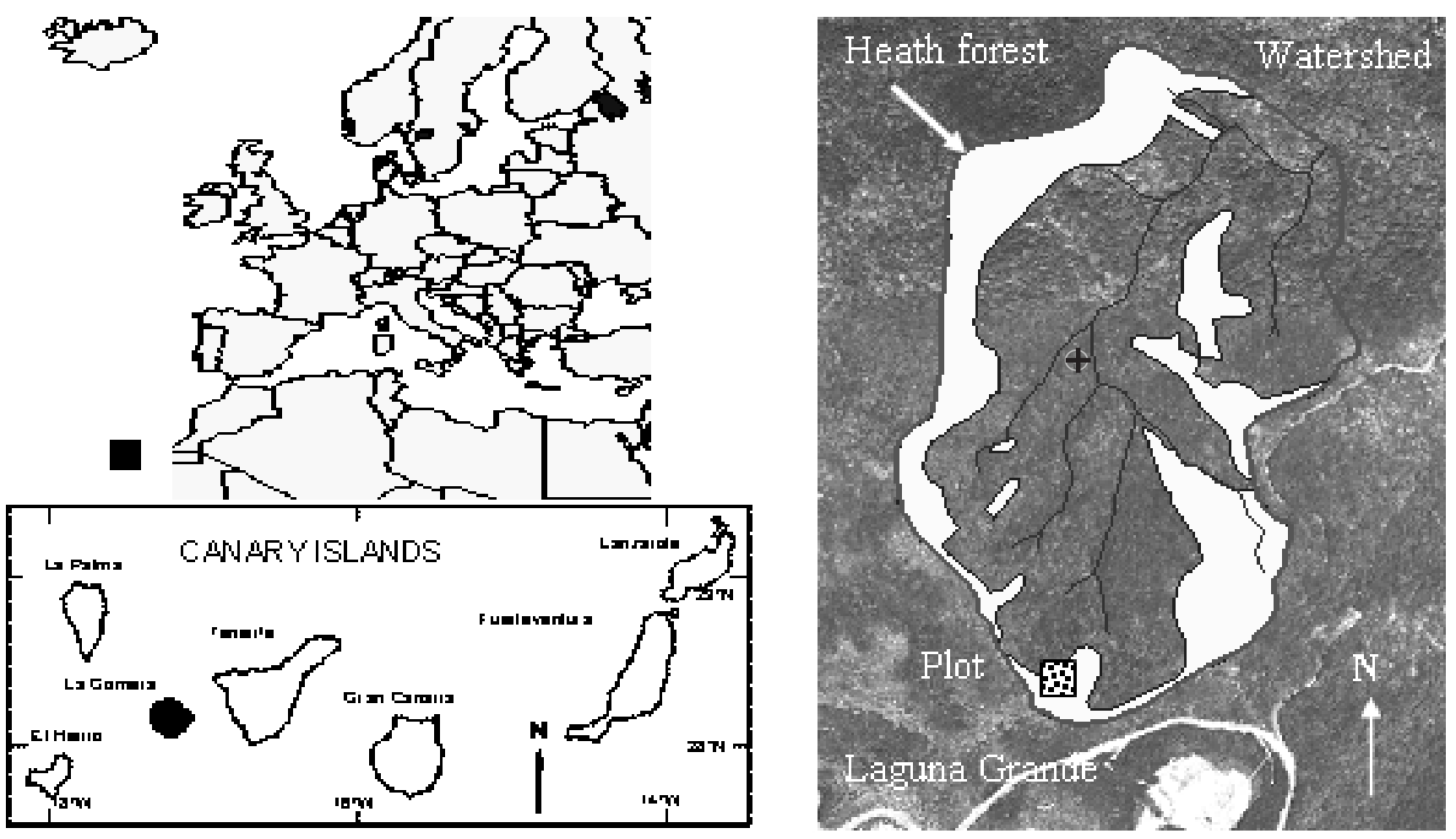

Fig. 1. (Left) Location of the Canary Islands and Gomera Island. (Right) Heath and Myrtle forest distribution at the catchment (white surfaces), location of both experimental plot and second pluviometer (+). (Catchment drawn by Ritter) 




Fig. 2. Experimental plot in the heath forest, showing distribution and diameter at breast height (DHB, $m$ ) of the sample trees (E. arborea with one pair of sap flow sensors = grey circle; M. faya with one pair of sap flow sensors = solid circle; M. faya with two pairs of sap flow sensors = hatched circle) plus location of meteorological station, dataloggers and TDR probes.

area index (LAI) of $4.2 \pm 1$ (Golubic, 2001). Average tree diameter at breast height (DHB) is $0.26 \mathrm{~m}$ (Fig.2) and the stand basal area is up to $68 \cdot 10^{-4} \mathrm{~m}^{2} \mathrm{~m}^{-2}$. Myrica faya represents the greatest proportion (57\%) of the stand basal area, followed by Erica arborea (33\%) and Laurus azorica $(10 \%)$. Physiological and structural studies on laurel forests in Agua Garcia (Tenerife), where trees are 10-15 m high with $5 \mathrm{~m}$ canopy thickness, gave a leaf area index of 7.8 (Morales et al., $1996 \mathrm{a}, \mathrm{b}$ ).

Actual climatic conditions were monitored by a meteorological station on a $12 \mathrm{~m}$ scaffolding tower at the experimental plot (Fig. 3); there, $2 \mathrm{~m}$ above the canopy, relative humidity $(\%)$ and air temperature $\left({ }^{\circ} \mathrm{C}\right)$ were recorded using a humidity and temperature transmitter (Campbell's 50Y + T351-RS /HMP45C + URS1 termo-hygrometer), global solar radiation ( $\mathrm{W} \mathrm{m}^{-2}$ ) was measured by a pyranometer (E.M's SP1110), wind speed ( $\mathrm{m} \mathrm{s}^{-1}$ ) by a switch anemometer (Campbell's A100R) and intercepted fog water $\left(\mathrm{L} \mathrm{m}^{-2}=\mathrm{mm}\right)$ by a screen fog collector and rainfall $\left(R_{f}, \mathrm{~mm}\right)$ in a Pronomamic Professional gauge. All variables were sampled at $3 \mathrm{~min}$ intervals and recorded every $15 \mathrm{~min}$ on a Combilog datalogger and then transmitted by GSM modem.

\section{WATER BALANCE}

The water balance comprises atmospheric and vegetative



Fig. 3. Meteorological instruments at the $12 \mathrm{~m}$ high station. 
processes as well as soil moisture storage within the catchment. At the crest, rainfall and fog water are the inputs (Garcia-Santos et al., 2004); evaporation, transpiration, surface runoff and soil water recharge are the outputs. Water interception and soil depression storage are the storages. The general water balance equation for the surface is:

$$
P_{n}=E t_{a}+S R+R
$$

where $P_{n}$ is the net precipitation reaching the ground surface through the canopy, $E t_{a}$ is the actual evapotranspiration, $S R$ is surface runoff, $\mathrm{R}$ is soil water recharge.

Soils are high organic (mean $28 \%$ of total soil dry matter). In addition, infiltration rates in forest soils are generally high (not measured here) and, although macropore flow is difficult to observe, surface runoff has been assumed to be negligible (i.e. the runoff coefficient under forests is only 0.1 according to Swiss rules: SNV 640351 ).

Hence, the water balance equation was simplified as:

$$
R=P_{n}-E t_{a}
$$

The annual water balance in $\mathrm{mm}$ of water at a monthly time scale was calculated from February 2003 to January 2004; daily scale was used in analysing stand transpiration measurements and a 15 min time scale in determining the ratio between rain falling through the canopy and gross rainfall

\section{GROSS RAINFALL AND FOG WATER}

\section{MEASUREMENTS ABOVE CANOPY}

Gross rainfall is measured by a tipping bucket rain gauge with a self-emptying spoon, a $0.02 \mathrm{~m}^{2}$ collecting surface, $0.25 \mathrm{~mm}$ resolution and without a wind shield. Because of the high wind effects, measurements at the gauge on the tower at the crest (Fig. 3) were rejected in favour of values from a rain gauge located $300 \mathrm{~m}$ from the experimental plot (Fig. 1), $2 \mathrm{~m}$ below the canopy on a tower $14 \mathrm{~m}$ high (1214 $\mathrm{m}$ a.s.l.) located on a level surface at $1214 \mathrm{~m}$ a.s.l. and free from obstacles, branches or leaves. Wind has only a minor effect on the catches in this gauge so exposure errors were ignored.

Potential fog water interception by the vegetation was quantified by a screen quarter fog collector (QFC) (Marzol, 2002 ) with a $0.5 \times 0.5 \mathrm{~m}$ Raschel-type collecting mesh of polypropylene, in a single layer, with a $65 \%$ shade coefficient. The mesh was oriented to the NE in the dominant wind direction and a gutter with a $0.06 \mathrm{~m}^{2}$ surface was installed below to collect drip water for measurement in another raingauge. Because rainfall and fog water often occur at the same time in this area, fog water interception accuracy may be affected, not only by the fixed orientation of the collector but also by the influence of rainfall on fog measurements. If fog measurements are collected only during periods without measurable rainfall inputs, fog water can also be underestimated. Isotope analysis of water from QFCs (Friedman, 1956; Mook and Vries, 2001) may help to reduce some of these inaccuracies. In this study, a correction factor of 3.6 per $\mathrm{m}^{2}$, estimated by Marzol (2002), was used to convert fog water volume to $\mathrm{mm}$ input when only fog water is collected.

\section{NET PRECIPITATION}

Total net precipitation or net water inputs $\left(P_{n}\right)$ is calculated as in Eqn. 3, where $T_{f}$ is throughfall that reaches the ground surface directly through spaces in the canopy and by dripping from the canopy, $S_{f}$ is stemflow and $E_{\mathrm{s}}$ is water that evaporates from the ground surface (soil and leaf litter surface water evaporation). Inside a laurel forest in Tenerife, Aschan et al., (1994) found high relative humidity, very low wind speeds and minimal radiation, which favoured low annual mean evaporation; therefore $E_{s}$ has been assumed to be negligible.

$$
P_{n}=T_{f}+S_{f}-E_{s}
$$

Estimation of net precipitation is subject to measurement errors because throughfall is highly variable spatially as well as between events and in different forest physiognomies (Puckett, 1991). However, in this study it was only possible to install two gauges, at $1 \mathrm{~m}$ above the ground surface, each with a collection surface increased to $0.2 \mathrm{~m}^{2}$ (total area of $0.4 \mathrm{~m}^{2}$ ). The gauges were protected by mesh shields (cleaned manually, initially every 15 days and later every 7 days) to prevent blockage of the orifices of the gauges by small heath needles and organic debris. Wind speed at ground level was expected to be low during the year $\left(0-2 \mathrm{~m} \mathrm{~s}^{-1}\right)$ but wind eddies around the unshielded gauges may reduce the catch of the smaller droplets of rain and fog by $0-15 \%$ (Yang et al., 1998; Dingman, 2002); thus an incoming water supplement of $10 \%$ (Yang et al., 1998) was added to monthly measured throughfall amounts (corrected throughfall). To estimate stemflow, the result of Gomez and Fernandez (2003) for similar heath forests $\left(2.8 \% R_{f}\right)$ was adopted.

Cloud forests intercept significant amounts of fog or occult or horizontal precipitation that is captured by the fog collector above the canopy. Part of the intercepted fog water is evaporated and the rest drips through the canopy. The amount of fog water and rain evaporated from the canopy (interception loss) is obtained by subtracting net 
precipitation from gross rainfall and fog water above the canopy (Bruijnzeel, 1999). The fog water that drips through the canopy is measured below the canopy by the gauges at ground level. Thus, throughfall amounts may consist partly of net rainfall $\left(R_{f n}\right)$ and partly of net fog water $\left(F W_{n}\right)$

$$
T_{f}=R_{f n}+F W_{n}
$$

While for cloud forests with mixed precipitation, isotopic analysis may be used to distinguish net fog water from net rainfall in Eqn. 4, it has not been applied in this study. One simple approach is to define net rainfall as throughfall $\left(T_{f}\right)$ for registered rainfall events only, even though throughfall is known to be highly variable (Leyton et al., 1967) and the rate determined here cannot be applied confidently to areas other than the current crest heath forest. Thus, daily rainfall events between February 2003 to January 2004 with very low wind speeds $\left(<2 \mathrm{~m} \mathrm{~s}^{-1}\right)$ were studied, together with daily throughflow and stemflow.

If the estimated monthly net rainfall plus monthly stemflow exceeded the monthly amount of throughfall on the basis of these empirical findings, rainfall was considered to be the only input of water to the soil. However, if this amount is lower than throughfall, the excess amount of water reaching the soil surface is assumed to be fog water drip from the crowns (Kashiyama, 1956; Harr, 1982).

\section{EVAPOTRANSPIRATION AND ACTUAL}

\section{EVAPOTRANSPIRATION}

Evapotranspiration in a forest without lakes and rivers is the sum of water evaporated from within the leaves of trees (stand transpiration), from vegetative surfaces (water storage on vegetation) and water evaporation from both soil surface and ground vegetation. From a surface energy balance or atmospheric perspective, annual actual evapotranspiration $\left(E t_{a}, \mathrm{~mm}\right.$ month $\left.^{-1}\right)$ in Eqn.2 is the combination of water intercepted by the canopy and transpiration by the green mass of the tree crowns $(T)$. Interception loss is the rain and fog water evaporated from the canopy and is obtained by subtracting throughfall plus stemflow from gross rainfall and fog water above the canopy (Bruijnzeel, 1999). Stand transpiration has been estimated by direct sap flow measurements in the experimental plot. Potential evapotranspiration $\left(E T_{p}, \mathrm{~mm}\right)$ is obtained using the PenmanFAO method (FAO, 1998), so the $E t_{d} / E T_{p}$ rate estimation reduces future $E t_{a}$ calculations to meteorological measurements. From a hydrological perspective, it is assumed that evaporation from vegetation is insignificant and water loss $\left(E t_{a}, \mathrm{~mm} \mathrm{month}^{-1}\right)$ in Eqn. 2 is attributed to stand transpiration only.

\section{SAP FLOW RATE MEASUREMENT}

Transpiration is assessed in two of the most abundant tree species of the crest forest (M. faya and E. arborea). The sap flow rates of three representative individuals of $M$. fay $a$ and of four sample trees of $E$. arborea (seven trees in all) were monitored continuously (Fig. 2) during 2003 and 2004 by the heat dissipation technique (Granier, 1987). One probe per tree was installed. Each sensor consists of two copper constantan thermocouple needles, $20 \mathrm{~mm}$ in length and $2 \mathrm{~mm}$ in diameter, inserted $20 \mathrm{~mm}$ into the stem of every sample tree. The two needles are installed one above the other, $10 \mathrm{~cm}$ apart. The upper needle has a constantan heating wire connected to the power supply $(120 \mathrm{~mA}$ constant current). The temperature difference $\left(\Delta T,{ }^{\circ} \mathrm{C}\right)$ between the heated upper needle and unheated lower reference needle is measured. In the absence of sap flow activity, the temperature difference is approximately $10-16^{\circ} \mathrm{C}$, but while sap is flowing, the temperature difference decreases because sap flow cools the heated needle. As sap velocity varies with the circumference of these trees (Jimenez et al., 2000), an additional pair of thermocouples was installed in one of the former M. faya trees (Fig. 2) to obtain supplementary information to scale the sap flow measurements. Data were recorded at $3 \mathrm{~min}$ intervals and stored every $15 \mathrm{~min}$ in a data logger (Combilog) and then transmitted by GSM modem. Sap flow per area $\left(\rho, \mathrm{ml} \mathrm{cm}^{-2} \mathrm{~min}^{-1}\right)$ and temperature difference measurements $(\Delta T)$ between the heated and reference needles are related to Granier's principles (Granier, 1987),

$$
\rho=0,714\left(\frac{\Delta \mathrm{T}_{\text {night }}}{\Delta \mathrm{T}}-1\right)^{1,231}
$$

$\Delta T_{\text {night }}$ is the temperature difference at night (usually taken as the peak nightime value of $\Delta T)$. Sap flux $\left(\mathrm{ml} \mathrm{min}^{-1}\right)$ is computed by multiplying $\rho$ by the cross-sectional area $\left(\mathrm{cm}^{2}\right)$ of active xylem of the tree (without bark) corresponding to the annuli insertion of the needle $(20 \mathrm{~mm})$ (Fig. 4).

\section{FROM SAP FLOW RATE MEASUREMENTS TO SAP FLOW OF THE TREE AND OF THE FOREST STAND}

E. arborea and M. faya trees are characterised by an active outer part of the xylem area, which is almost half of the DBH (without bark), whereas the inner part is nonconducting (Jimenez et al., 2000) (Fig. 4). In the study, the length of thermocouples is less than the conducting xylem radius of the trees. Therefore, the velocity of sap flow for

"UP GmbH, http://www.upgmbh.com/support/pdf-files/ xylem2000.pdf 


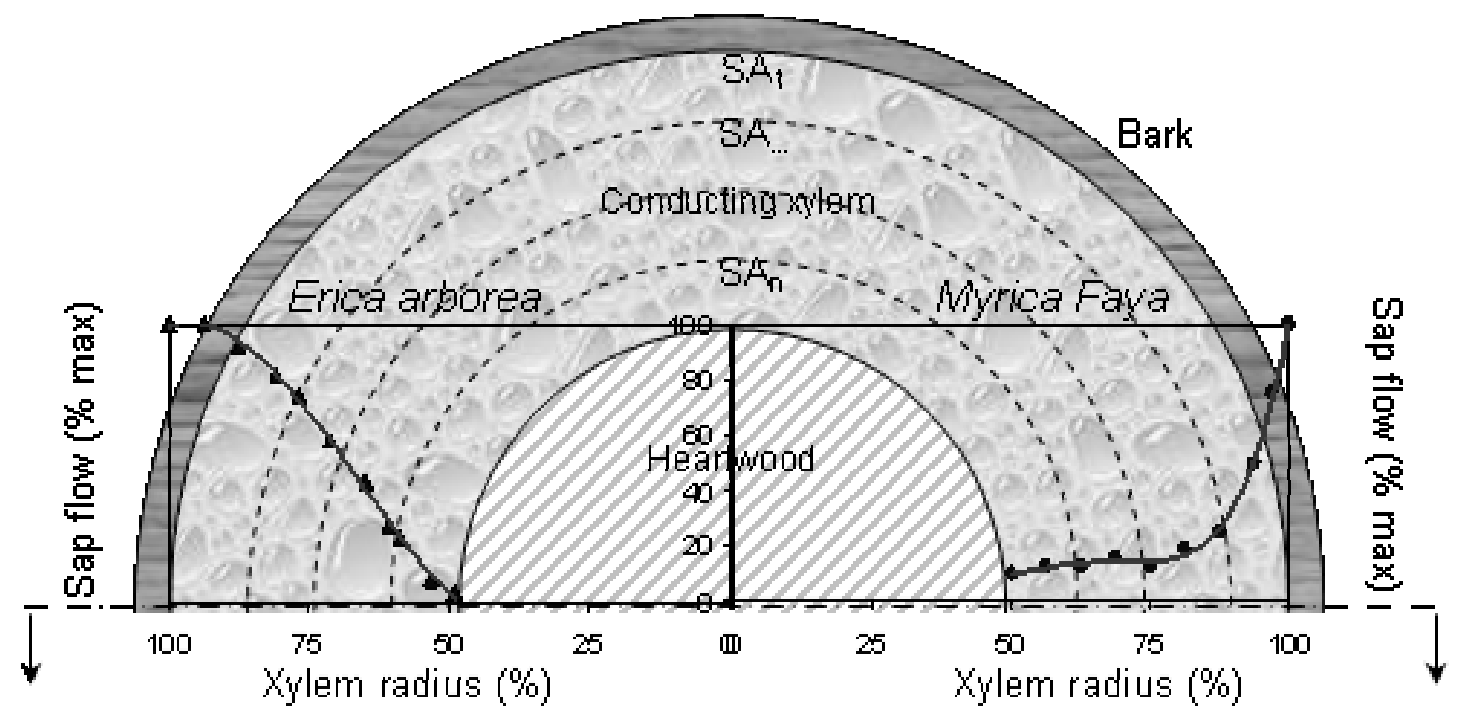

Fig. 4. Description of the cross-sectional area (bark conducting xylem divided in $210^{-2} \mathrm{~m}$ annuli [SA] and heartwood) of Erica arborea. and Myrica faya and their radial pattern of sap flow per area based on the Jimenez et al. (2000) study in a laurel forest in Tenerife (Spain). Left: Radial pattern of sap flow in E. arborea expressed as a percentage of its maximum versus distance along the xylem radius expressed as a percentage. Modified curve based on the curve obtained by Jimenez et al. (2000). Right: Radial pattern of sap flow in M. faya corresponding to $2 B^{*}$ type trees in Jimenez et al., (2000) under conditions of high flow expressed as a percentage of its maximum versus distance along the xylem radius expressed as a percentage.

$* 2=$ Outer part of xylem area is conducting and inner part is non-conducting.

$B=$ Narrow peak in the outer part of xylem area.

the whole tree is obtained by integrating the velocity of sap flow along the radial conducting xylem radius of the tree at $2 \cdot 10^{-2} \mathrm{~m}$ intervals and then adding them up. The fitted curves obtained by Jimenez et al., (2000) (Fig. 4) were used to represent the radial pattern of sap flow per area, which is expressed as a percentage of its maximum versus distance along the xylem radius. L. azorica transpiration has been obtained by using a modified Gompertz equation, which relates sap flow rate in individual trees to their basal area (Jimenez et al., 1996).

The measured sap flow of the individual sample tree $\left(\mathrm{L} \mathrm{d}^{-1}\right)$ is scaled up to the experimental stand by considering the basal areas of all the sample trees along with the forest inventory data of the whole experimental plot (Fig. 2).

\section{Results and discussion}

ANNUAL GROSS RAINFALL AND FOG WATER PATTERN

Seasonal gross rainfall and intercepted fog water distributions are shown in Fig. 5. Total annual water income at crest heath added up to $1440 \pm 98 \mathrm{~mm}_{\text {year }}{ }^{-1}$, consisting of $770 \pm 82.2 \mathrm{~mm}$ year ${ }^{-1}$ rainfall and $670 \pm 45 \mathrm{~mm}$ year $^{-1}$ fog water above the canopy. Over the year, rainfall was highest in autumn and least in summer. The maximum rainfall in a month was $262 \pm 14.4 \mathrm{~mm} \mathrm{month}^{-1}$ in November and the minimum was $0.3 \pm 0.04 \mathrm{~mm} \mathrm{month}^{-1}$ in August. Unusually low amounts were observed during the generally wet December and January period, when dry Saharan winds occurred.

In the period studied, fog events were observed every month. There was a maximum incidence of fog in spring 2003 and a minimum in summer 2003. The maximum fog water accumulation per month was 129 and $131 \mathrm{~mm} \mathrm{month}^{-1}$ in February and May 2003 respectively, with a minimum of $7 \mathrm{~mm} \mathrm{month}^{-1}$ in August.

On a daily basis, the maximum rainfall was $55.7 \mathrm{~mm} \mathrm{~d}^{-1}$ on 1 November and maximum fog water was $44 \mathrm{~mm} \mathrm{~d}^{-1}$



Fig. 5. Annual gross rainfall and fog water (fog intercepted by QFC) distribution. Vertical lines represent one standard deviation from the mean. 
(daily mean wind speed $=2.3 \mathrm{~m} \mathrm{~s}^{-1}$ ) on the 4 April. These results contrast with Marzol's (2002) finding that the highest amount of fog in summer coincided with the highest fog incidence in the Canary Islands (Dorta, 1996). The difference in results may be explained on the basis of the altitude of the thermal inversion in the Canaries in summer (approximately $600 \mathrm{~m}$ a.s.1.) (Dorta, 1996). Marzol's plot is under the influence of the 'sea of clouds' in summer and the area studied here is at $1300 \mathrm{~m}$ a.s.l., above the 'sea of clouds', the influence of which was, therefore, minor.

\section{PATTERNS OF ANNUAL THROUGHFALL AND OF WATER STORAGE ON VEGETATION}

Water entering the system penetrates the canopy according to the amount of rainfall and fog water as well as their distribution in time. In the period studied, annual corrected throughfall was $898 \pm 89.1 \mathrm{~mm}^{-1} \mathrm{year}^{-1}$ and annual stemflow was $22 \pm 2.3 \mathrm{~mm}_{\text {year }}{ }^{-1}$ (920 $\mathrm{mm} \mathrm{year}^{-1}$ net water input). Annual net water gain as a percentage of total water income was $64 \%$ and annual water intercepted by the vegetation was $36 \%\left(522 \pm 38.4 \mathrm{~mm} \mathrm{year}^{-1}\right)$, which is assumed to be evaporated back to the atmosphere. Comparison of these results with those of Aboal (1998) for a laurel forest in Tenerife $(57 \%$ of net water gain and $43 \%$ of interception loss), shows that the soil surface under crest heath forest gains $10 \%$ of net water.

On a monthly basis, gross rainfall $\left(R_{f}, \mathrm{~mm}\right)$ and net water gain $\left(P_{n}, \mathrm{~mm}\right)$ were related linearly with a coefficient of determination of $\mathrm{r}^{2}=0.94$ (Fig. 6)

$$
P_{n}=1.05 \mathrm{R}_{\mathrm{f}}+7.4
$$

This equation shows that an additional water source is entering the soil surface system.

Seasonal total water income (gross rainfall plus fog water), corrected throughfall in the pluviometers and the resulting water intercepted by the humid (dry in summer) crest heath forest patterns are shown in Fig. 7, which shows that monthly net water gain rate is highly variable during the year; net water gain as a percentage of total water income ranges from $0.06 \%$ in August $(0.4 \mathrm{~mm})$ and $0.13-0.16 \%$ in May and June respectively $(19.3 \mathrm{~mm}$ and $7.7 \mathrm{~mm}$ ) to $0.94 \%$ in November (293 mm).

Water intercepted by the vegetation (water loss) as a percentage of total water income (Fig. 6), ranges from $94 \%$ in August ( $7 \mathrm{~mm}$ ) and $85-88 \%$ in May and June respectively (124 $\mathrm{mm}$ and $40 \mathrm{~mm})$ to $0.03 \%$ in November $(10 \mathrm{~mm})$.

The highest monthly fog water amount was $131 \mathrm{~mm}$ in May 2003 (12 $\mathrm{mm}$ of gross rainfall), when interception at the crest heath forest was $124 \mathrm{~mm}$ and throughfall was only

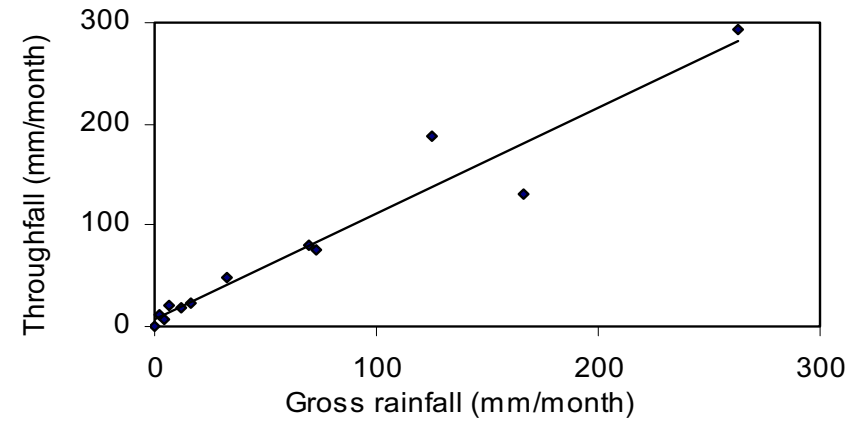

Fig. 6. Monthly gross rainfall and measured monthly net precipitation in $2003(n=11)$ in a crest heath forest (degraded laurel forest) in the National Park of Garajonay (La Gomera Island, Spain).

$18 \mathrm{~mm}$. In August 2003, the driest month ( $0.3 \mathrm{~mm}$ of gross rainfall and $7 \mathrm{~mm}$ of fog water), almost all fog water (94\%) remained on the vegetation. Fog water, linearly related to water storage on vegetation during 2003 (Fig.8), resulting in a coefficient of determination, $\mathrm{r}^{2}=0.91$.

These results show that the maximum water gain is greatest in the rainiest months in autumn and least in spring and summer, when fog water was highest and rainfall was moderate-low.

\section{NET RAINFALL FORECAST FROM THROUGHFALL}

Rainfall events above the canopy without fog water and low wind speeds were observed on only 12 days during 2003-2004 in which 103 individual rain events occurred of 15 min duration. On the remaining days $(n=353)$, mixed

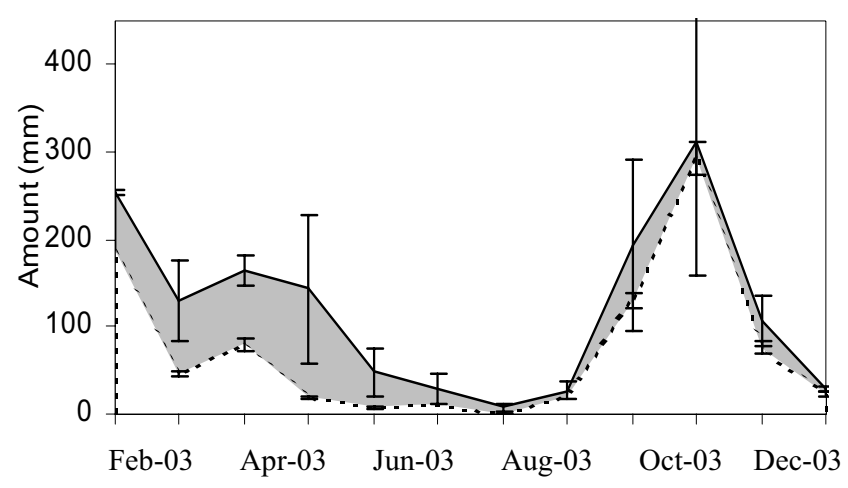

Water inputs ---- Corrected throughfall Water intercepted by the canopy

Fig. 7. Seasonal total water input above canopy and throughfall patterns at $1300 \mathrm{~m}$ in a humid (dry in summer) crest heath forest in the National Park of Garajonay, Gomera Island, Spain. Vertical bars represent \pm one standard deviation. 


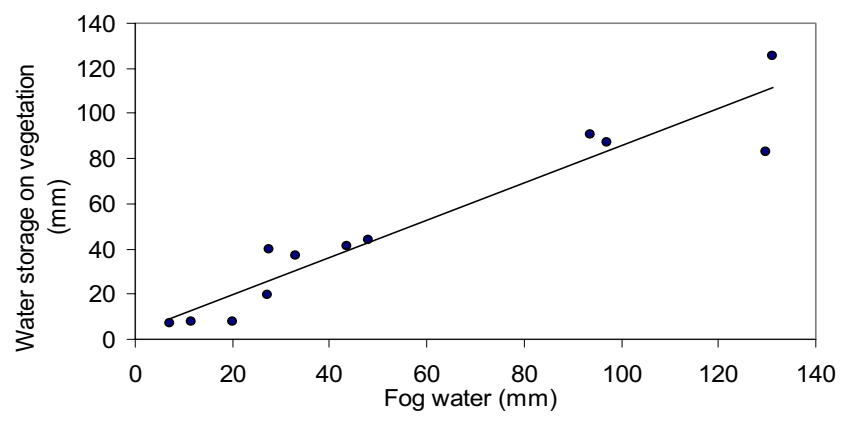

Fig. 8. Monthly fog water intercepted by the collector (QFC) related to water storage on heath wood-land at the crest, which results from the difference between total water inputs and throughfall.

precipitation (pluviometer and QFC registered water input) occurred with fog water and wind speeds $>2 \mathrm{~m} \mathrm{~s}^{-1}$. Daily gross rainfall $\left(R_{f}, \mathrm{~mm} \mathrm{~d}^{-1}\right)$ and throughfall $\left(T_{f}, \mathrm{~mm} \mathrm{~d}^{-1}\right)$ under these meteorological conditions $(n=12)$ were linearly related with $r^{2}=0.99$ (Fig. 9)

$$
R=0.96 R_{f n}+1.94
$$

This equation allows an estimation of heath wood land canopy capacity, i.e. the amount of water captured in the canopy after rainfall and throughfall have ceased. The calculated daily canopy capacity at the crest amounts to $0.57 \mathrm{~mm}$. Comparing this result with that of Aboal (1998) shows that higher amounts of rainfall $(2.45 \mathrm{~mm})$ were required to saturate the laurel forest canopy in Agua García, Tenerife. These results should be interpreted with care because many more pluviometers beneath the canopy are essential to estimate the rainfall through the canopy. Moreover, variability may be affected by the size, length and intensity of the rainfall events (Leyton et al., 1967; Maloney et al., 2002).

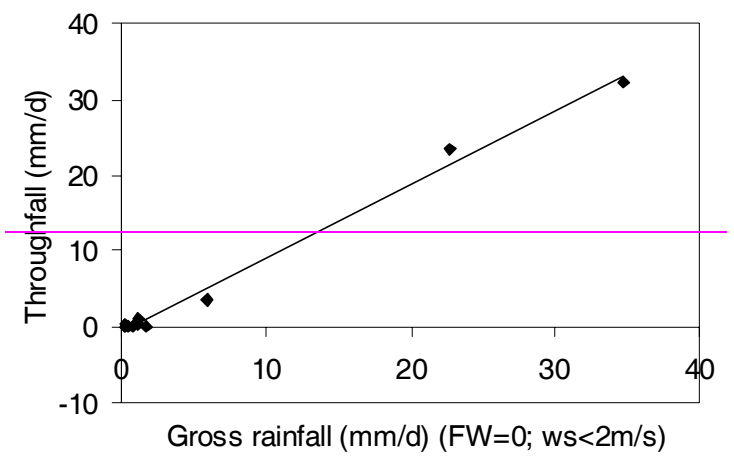

Fig. 9. Daily throughfall ( $\mathrm{mm}^{-1}$ ) related to gross rainfall above canopy $\left(\mathrm{mm} \mathrm{d}^{-1}\right)$, without fog water events and very low wind speed $<2 \mathrm{~m} \mathrm{~s}^{-1}$, from February 2003 to January $2004(n=12)$ in a crest heath forest (degraded laurel forest) located in the National Park of Garajonay (La Gomera Island, Spain).

\section{METEOROLOGICAL INFLUENCES ON HEATH} WOOD-LAND TRANSPIRATION DURING 2003/04

Annual variations in the principal meteorological factors are shown in Fig.10. Global radiation was high in summer with many oscillations due to clouds. Monthly stand transpiration was related, linearly, to global radiation with $\mathrm{r}^{2}=0.73$. The mean air temperature was $10^{\circ} \mathrm{C}$ in winter and $18^{\circ} \mathrm{C}$ in summer. Transpiration followed the evaporative demand over the year (Fig. 10). Monthly mean temperature and mean vapour pressure deficit were related to stand transpiration with $r^{2}=0.68$ and $r^{2}=0.73$ respectively. The maximum values of stand transpiration $\left(3 \mathrm{~mm} \mathrm{~d}^{-1}\right)$ occurred mainly when days were clear and vapour pressure deficit high. This mean value is lower than that obtained by Jimenez et al. (1998) in Tenerife. The dependence on evaporative conditions confirms the relatively weak stomatal control by M. faya and E. arborea reported by Zohlen et al., (1995) for a laurel forest in Tenerife. Monthly stand transpiration had a polynomial relation to gross rainfall with a $\mathrm{r}^{2}=0.91$.

\section{HEATH WOOD-LAND EVAPOTRANSPIRATION AND} ACTUAL EVAPOTRANSPIRATION

Measured annual net precipitation was $919 \pm 91.3 \mathrm{~mm}^{-1} \mathrm{mer}^{-1}$, stand transpiration was $400 \pm 15 \mathrm{~mm}$ year $^{-1} \mathrm{ha}^{-1}$ (48\% of annual net precipitation), which is in the range reported for comparable evergreen laurel forests in Tenerife (Jimenez et al., 1996; 1999); water storage on the vegetation was $520 \pm 38.4 \mathrm{~mm} \mathrm{year}^{-1}$ so annual heath woodland evapotranspiration was $920 \pm 42 \mathrm{~mm}_{\text {year }}{ }^{-1}$. These results are consistent with studies in Tenerife (Aboal, 1998; Morales et al., 2003),

Hence, evapotranspiration in the forest is a very important component of the hydrological cycle; it accounts, annually, for more than half the water income. Estimation of evapotranspiration and potential evapotranspiration from climatological measurements were similar $(950 \pm 28.4 \mathrm{~mm}$ year $^{-1}$ ), so annual potential evapotranspiration may be considered as actual evapotranspiration in a humid (dry in summer) crest heath forest. Monthly transpiration T (mm) was related linearly to potential evapotranspiration $\left(E T_{p}\right.$, mm) with $\mathrm{r}^{2}=0.86$ (Eqn. 5) (Fig. 11),

$$
E T_{p}=1.75 T+21
$$

Daily $T(\mathrm{~mm})$ was related to potential evapotranspiration $E T_{p}, \mathrm{~mm}$ with $\mathrm{r}^{2}=0.67$ (Eqn. 6) (Fig. 12),

$$
E T_{p}=2 T+0.3
$$

and the $T / E T_{p}$ ratio was 0.42 . 
Water dynamics in a laurel montane cloud forest in the Garajonay National Park (Canary Islands, Spain)
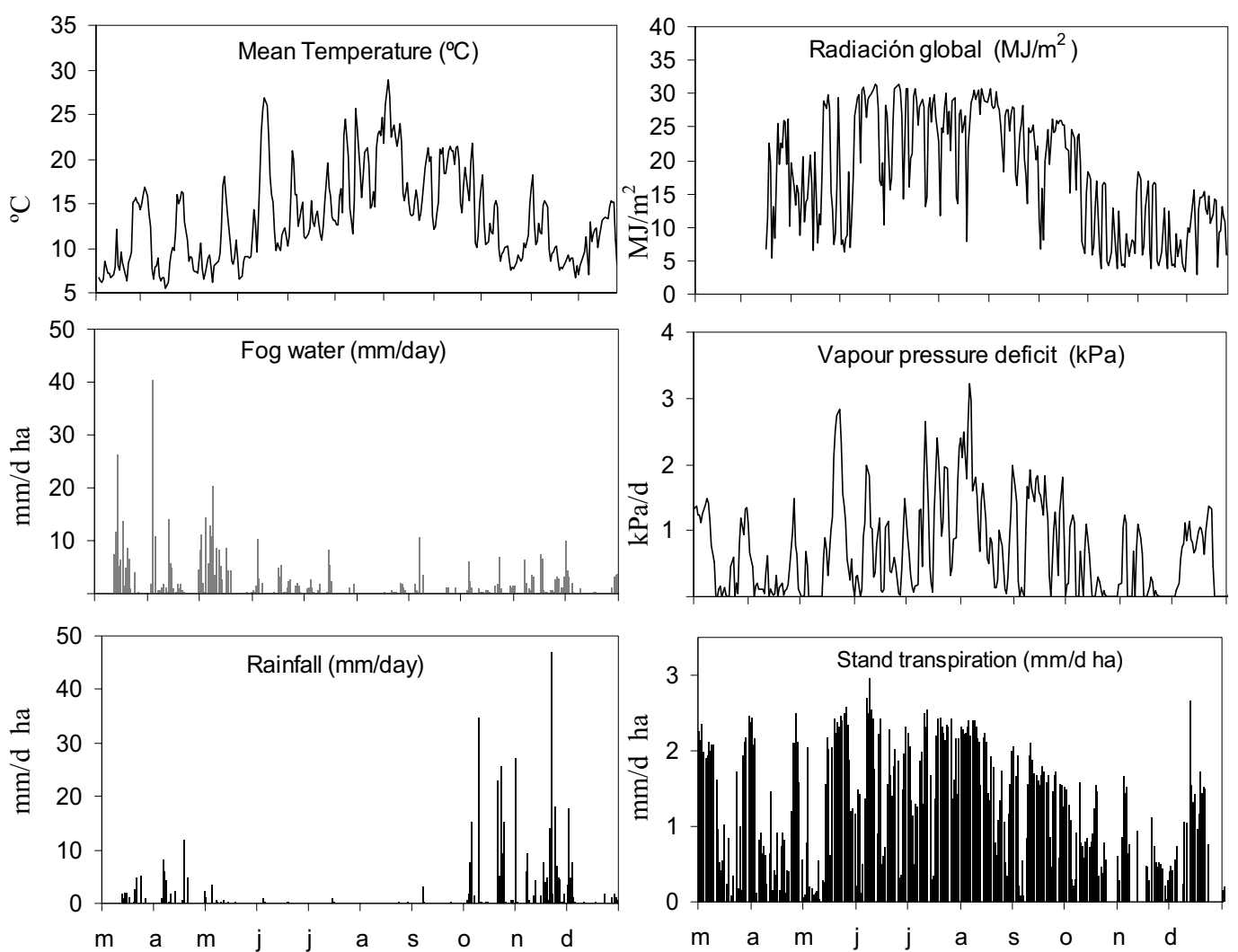

Fig. 10. Annual temperature, global radiation, intercepted fog water, vapour pressure deficit, gross rainfall and stand transpiration pattern of a humid (dry summer) crest heath forest.

Potential evapotranspiration was related to throughfall (Fig. 13) with accountable variance $\left(r^{2}=0.73\right)$

$$
E T_{p}=133 T f^{0.15}
$$

This regression is more precise when throughfall values are high.

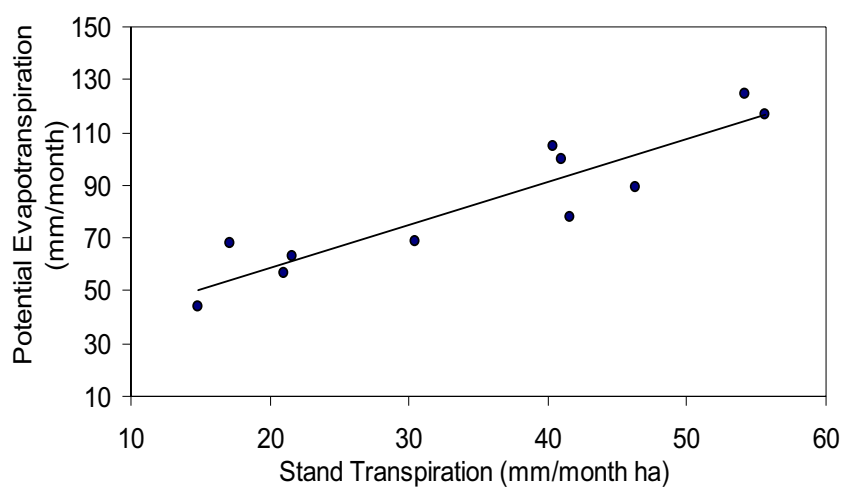

Fig. 11. Monthly stand transpiration and potential evapotranspiration in 2003/04 in a humid crest heath forest (degraded laurel forest) in Gomera Island (Spain).

\section{WATER BALANCE}

Average annual gross rainfall and intercepted fog water above the canopy during February 2003 and January 2004 amounted to $770 \pm 82.2 \mathrm{~mm}_{\text {year }}^{-1}$ and $670 \pm 45 \mathrm{~mm}$ year ${ }^{-1}$ respectively. Annual average water remaining on the vegetation $\left(522 \pm 38.4 \mathrm{~mm} \mathrm{year}^{-1}\right)$ was higher than that obtained by Aboal et al., (1999a, b), which were $239 \mathrm{~mm}$

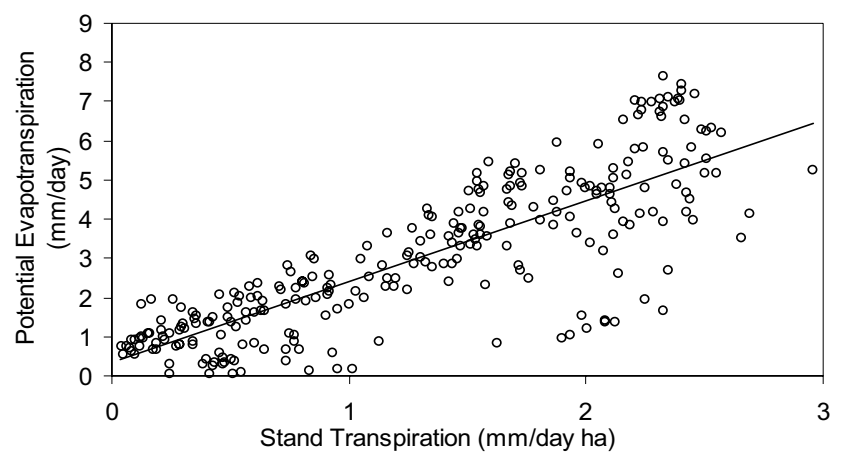

Fig. 12. Daily stand transpiration and potential evapotranspiration in 2003/04 in a humid crest heath forest (degraded laurel forest), in Gomera Island (Spain). 


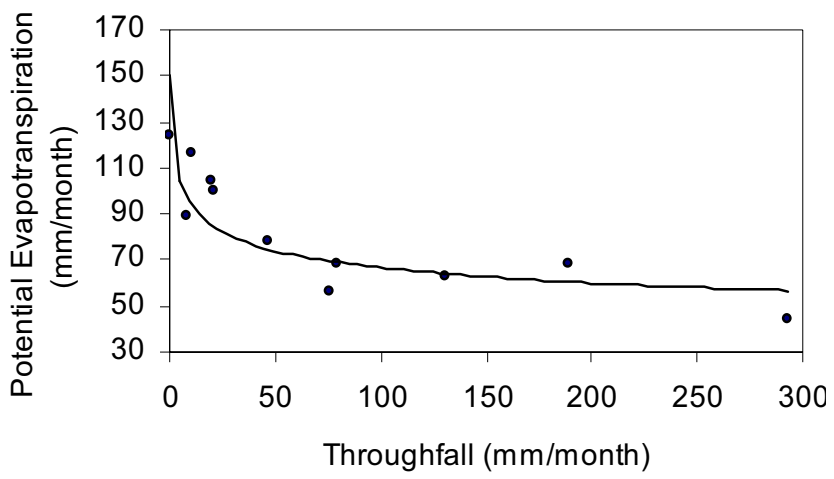

Fig. 13. Monthly corrected throughfall and potential evapotranspiration in 2003/04 in a humid crest heath forest (degraded laurel forest) in Gomera Island (Spain).

year $^{-1}$ when gross rainfall was $797 \mathrm{~mm}$ year $^{-1}$ (1993-94) and $262 \mathrm{~mm}_{\text {year }}^{-1}$ when gross rainfall was $625 \mathrm{~mm}^{-1}$ year $^{-1}$ (1995). These differences may reflect the fact that fog water lingered longer on the vegetation of the crest heath forest than on the forest studied by Aboal in Tenerife.

An annual water balance on a soil surface basis, where water evaporated from vegetation is excluded but water losses are subtracted according to stand transpiration measurements $\left(400 \pm 15 \mathrm{~mm}_{\text {year }}{ }^{-1}\right)$, amounts to a net water input of $520 \pm 102.3 \mathrm{~mm}_{\text {year }}{ }^{-1}$. These inputs are presumed to contribute directly to the soil water recharge. This high positive water balance contrasts with the results of Aboal et al., (1999 a, b) who obtained -78 $\mathrm{mm} \mathrm{year}^{-1}$ in 1993-94 and $+69 \mathrm{~mm}^{\text {year }}{ }^{-1}$ in 1995 , possibly due to a lack of fog water interception above the canopy.

Forest stand transpiration represents about $50 \%$ of net annual inputs but, during the five dry months (from May to September 2003), the system's loss of water was controlled principally by transpiration. Total net water supply from May to September of $60 \pm 8.6 \mathrm{~mm}$, (net fog water might contribute $36.3 \pm 5.8 \mathrm{~mm}$ and net rainfall $24 \pm 4.2 \mathrm{~mm}$ ), was insufficient to satisfy the water demand of the vegetation $(240 \pm 7.0 \mathrm{~mm})$. In the annual water balance of a catchment or larger forested area, the positive role of undisturbed laurel forests which transpire less water than the inputs of rain and fog precipitation, is emphasised and verified.

\section{Conclusions}

Annual fog water intercepted by the fog collector in the National Park of Garajonay almost matched incoming rainfall in this crest heath forest and occurred during every month of the year. Nevertheless, canopy efficiency in intercepting fog water should be studied in more detail to determine the interception of vegetation more accurately.
Separating rain and fog water values from total throughfall is inaccurate and provides only an initial estimate of the net fog water input to the soil. Thus, fog water might well have contributed twice that of the net rainfall amount during the five dry months at the crest heath forest. An analysis of water isotopes would enable these conclusions to be investigated. In this humid crest heath forest, with fog incidence in all seasons, evapotranspiration is limited by the available energy so that annual actual evapotranspiration was essentially equal to annual potential evapotranspiration. This study shows that fog interception loss and occult precipitation through the canopy should be included in any hydrological, physiological or meteorological study in Gomera in crest heath forest oriented to the north and located between 900 and $1300 \mathrm{~m}$ a.s.1.

Finally, precise soil water contents should be measured throughout the soil profile at spatially representative locations and zero flux plane studies should be made to evaluate the recharge to groundwater.

\section{Acknowledgement}

This research has been sponsored in part by the Spanish Instituto Nacional de Investigaciones Agrarias (I.N.I.A. project: RTA01-97) and the Instituto Canario de Investigaciones Agrarias. The authors acknowledge I.N.I.A. and the members of the National Park of Garajonay and RTA01-97 project (Dr. C. Regalado, Dr. J.M. Hernández, A. Socorro, Dr. A. Ritter and N. G. Pérez). In particular, the authors thank L. A. Gómez for assistance in the field.

\section{References}

Aboal, J.R., 1998. Los flujos netos hidrológicos y químicos asociados. PhD. Dpt. de Biología Vegetal. Univ. de La Laguna, Spain.

Aboal, J.R., Jiménez, M.S., Morales, D. and Hernández, J.M., 1999a. Rainfall interception in laurel forest in the Canary Islands. Agr. Forest Meteorol., 97, 73-86.

Aboal, J.R., Morales, D., Hernández, J.M. and Jiménez, M.S., $1999 \mathrm{~b}$. The measurement and modelling of the variation of stemflow in a laurel forest in Tenerife, Canary Islands. $J$. Hydrol., 221, 161-175

Aboal, J.R., Jiménez, M.S. and Morales, D., 2000. Evaluación de la precipitación de niebla a través de la precipitación penetrante. Vieraea 28, 15-29.

Aschan, G., Jimenez, M.S., Morales, D. and Lösch, R., 1994. Microclimatic aspects of a Laurel forest in Tenerife. Vieraea 23, 125-141.

Aschan, G., Lösch, R., Jiménez, M.S. and Morales, D., 1997. Energiebilanz von Waldbeständen in nicht-idealem GeländeAbschätzungen auf der Grundlage von standörtlicher Klimaerfassung und flankierenden Gaswechselmessungen am Beispiel eines Lorbeerwaldbestandes auf Teneriffa. EsoSystem Suppl.-Bd 20, 145-160. 
Bruijnzeel, L.A., 1999. Hydrology of tropical montane cloud forests: A reassessment. $2^{\text {nd }}$ International Colloquium. Hydrol. Water Manage. Humid Trop., 6, 353-383.

Cavelier, J. and Goldstein, G., 1989. Mist and fog interception in elfin cloud forests in Colombia and Venezuela. J. Trop. Ecol., 5, 309-322.

Consejo Insular de Aguas de Tenerife, 2000. http:// www.aguastenerife.org

Dingman, S.L., 2002, 1994. Physical hydrology, Second Edition. Prentice-Hall, Inc., 94-165.

Dorta, P., 1996. Las inversiones térmicas en Canarias. Invest. Geogr., 15, 109-124.

F.A.O., 1998. Crop evapotranspiration. Guidelines for computing crop water requirements. FAO Technical Report No. 56.

García-Santos, G., Regalado, C.M., Hernández Moreno, J.M., Pérez Buenafuente, A. and Socorro, A.R., 2003. Caracterización de la zona no saturada de un bosque de laurisilva en el Parque Nacional de Garajonay: Hidrofobia e implicaciones hidrológicas. VI Congr. Zona no saturada, Valladolid.

García-Santos, G., Regalado, C.M., Ritter, A. and Marzol, V., 2004. Water balance and fog features in a laurisilva subtropical montane cloud forest at the Garajonay National Park. $2^{\text {nd }}$ Intl. Symp. Mountains in the mist: Science for conserving and managing tropical montane cloud forest, Hawaii. (In press).

Golubic, I., 2001. Vegetationskundliche Analyse von Lorbeerwaldund ähnlichen Beständen im Rahmen einer Untersuchung des Landschaftswasserhaushaltes im Garajonay Nationalpark La Gomera. Diploma Thesis, Univ. Essen, Germany.

Granier, A., 1987. Evaluation of transpiration in a Douglas fir stand by means of sap flow measurements. Tree Physiol., 3, 309-320.

Gómez, L. and Fernández, A., 2003. Primeros resultados del seguimiento de la precipitación de la niebla en el P.N. de Garajonay. Univ. de La Laguna, Spain.

Harr, R.D., 1982. Fog drip in the Bull Run municipal watershed, Oregon. Water Resour. Bull. 18, 785-789.

Höllermann, P., 1981. Microenvironmental studies in the laurel forest of the Canary Islands. Mt. Res. Dev., 1, 193-207.

Jimenez, M.S., Cermák, J., Kucera, J. and Morales, D., 1996. Laurel forest in Tenerife, Canary Islands: the annual course of sap flow in Laurus trees and stand. J. Hydrol., 183, 307-321.

Jimenez, M.S., Morales, D., Kucera, J. and Cermák, J., 1999. The annual course of transpiration in a laurel forest of Tenerife. Estimation with M. faya. Phyton (Austria), 39, 85-90.

Jimenez, M.S., Nadezhdina, N., Cermák, J. and Morales, D. 2000. Radial variation in sap flow in five laurel forest tree species in Tenerife, Canary Islands. Tree Physiol., 20, 1149-1156.
Kämmer, F., 1974. Klima und vegetation auf Tenerife, besonders im Hinblick auf den Nebelniederschlag. Scripta Geobotanica, 78, Göttingen, Germany.

Kashiyama, T., 1956. Decrease of sea-fog density by a model shelterbelt. Proc. of the $12^{\text {th }}$ Congr. of the Intl. Union of Forestry Resesarch Organizations Oxford, UK.

Leyton, L., Reynolds, E.R.C. and Thompson, F.B., 1967. Rainfall interception in forest and moorland. In: International Symposium on Forest Hydrology, W.E. Sopper and H.W. Lull (Eds.). Pergamon Press, New York, USA. 163-168

Maloney, D., Bennett, S., De Groot, A. and Banner, A., 2002. Canopy interception in a hypermaritime forest on the North Coast of British Columbia. Forest Sci. Prince Rupert Forest Region 49, November 2002.

Marzol, M.V., 1993. Tipificación de las tres situaciones atmosféricas más importantes en las Islas Canarias. Strenae Emmanuelae Marrero Oblatae. Univ. de La Laguna, Spain. 7985.

Marzol, M.V., 2002. Fog water collection in a rural park in the Canary Islands (Spain). Atmos. Res., 64, 239-250.

Marzol, M.V., Sanchez-Megía, J. and Santana, L., 1990. El clima de Garajonay en el sector insular. Parque Nacional de Garajonay Patrimonio Mundial. Col. Técnica (ICONA) Madrid, Spain.

Morales, D., Jiménez, M.S., Gonzalez-Rodriguez, A. and Cermák, J., 1996. Laurel forest in Tenerife, Canary Island: I. The site, stand structure and leaf area distribution. Trees, 11, 34-40.

Morales, D., Gonzalez-Rodriguez, A.M. and Jiménez, M.S., 2003. Ecofisiología de la laurisilva canaria. Ecosistemas XII, 1.

Pérez de Paz, P.L., del Arco Aguilar, M., Acebes, J.R. and Wildpret, W., 1990. La vegetación cormofitica (vascular) del P.N. de Garajonay. P. N. de Garajonay, Patrimonio Mundial. Col. Técnica (ICONA) Madrid, Spain.

Puckett, I.J., 1991. Spatial variability and collector requirements for smapling throughfall volume and chemistry under a mixedhardwood canopy. Can. J. Forest Res., 21, 1581-1588.

Yang, D., Goodison, B.E., Ishida, S. and Benson, C.S., 1998. Adjustment of daily precipitation data at 10 climate stations in Alaska: Application of World Meteorological Organization intercomparison results. Water Resour. Res., 34, 241-256.

Zohlen, A., Gonzalez-Rodriguez, A., Jimenez, M.S., Lösch, R. and Morales, D., 1995. Transpiration and stomatal regulation in laurel forest trees measured in the Spring. Vieraea, 24, 91104. 